\title{
Primum non dosere
}

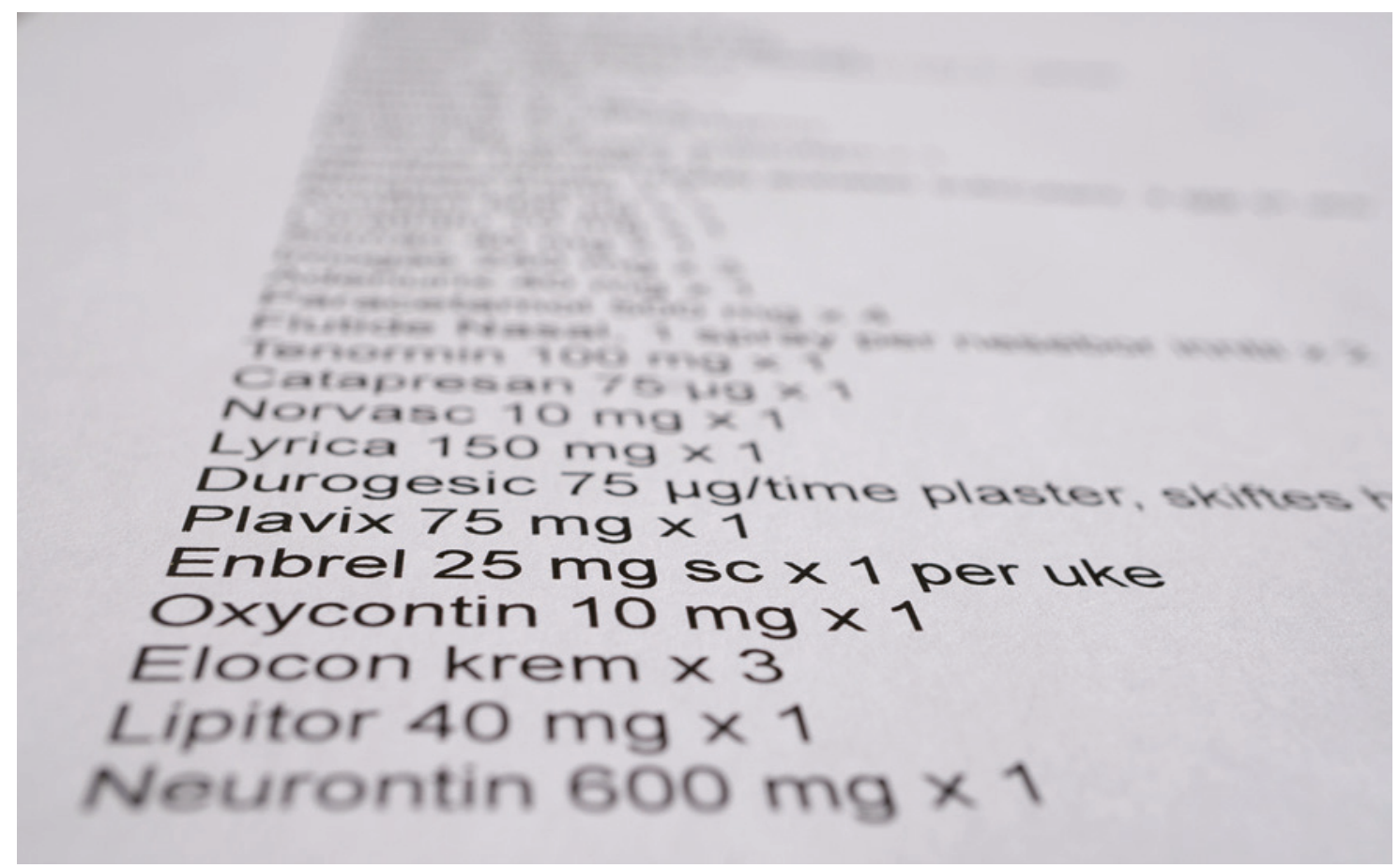

Bildet viser en av de lengste medisinlistene vi har sett. Denne pasienten fikk forskrevet hele 43 legemidler, mange av dem helt åpenbart unødvendige.

I løpet av våre stadig lengre liv rekker de fleste av oss å få sykdommer eller risikofaktorer for sykdom som krever medikamentell intervensjon. Med en pille mot alt som er ille, kan medisinlistene fort bli lange og problemene mange. Veien til farlige interaksjoner er som kjent brolagt med både gode intensjoner og riktige indikasjoner.

Medisinforskrivning er som matematikk på barneskolen: Addisjon er mye enklere enn subtraksjon. Men vi må lære oss begge deler.

\section{Christine Karlsen}

christine.karlsen@vikhammerlegekontor.no

Vikhammer legekontor, Vikhammer og

Helseøkonomiforvaltningen (HELFO)

Andreas Austgulen Westin

Avdeling for klinisk farmakologi

St. Olavs hospital, Trondheim

og

Helseøkonomiforvaltningen (HELFO)

Christine Karlsen (f. 1982) er fastlege og rådgivende lege.

Forfatter har fylt ut ICMJE-skjemaet og oppgir

ingen interessekonflikter.
Andreas Austgulen Westin (f. 1977) er overlege og rådgivende lege.

Forfatter har fylt ut ICMJE-skjemaet og oppgir ingen interessekonflikter.

Mottatt 22.9. 2015, første revisjon innsendt 5.10. 2015, godkjent 7.10. 2015. Redaktør: Lise Mørkved Helsingen. 